\title{
Research Paper \\ Construction and validation of the preliminary version of the pictorial-computer test for executive functions
}

\footnotetext{
Mohsen Rafikhah ${ }^{1}$, AliAkbar Arjmandnia ${ }^{2}$, Mohsen Shokoohi-Yekta ${ }^{3}$, Saeed HasanZadeh ${ }^{2}$, Ali MoghaddamZadeh ${ }^{4}$

1. Ph.D Student in Psychology and Education of Exceptional Children, Faculty of Psychology and Educational, University of Tehran, Tehran, Iran.

2. Associate Professor, Department of Psychology and Education for Exceptional Children, Faculty of Psychology and Education, University of Tehran. Tehran, Iran.

3. Professor, Psychology and Education of Exceptional Children, Department of Psychology, University of Tehran, Iran. 4. Assistant Professor, Faculty of Psychology and Educational, University of Tehran, Tehran, Iran.
}

Citation: Rafikhah M, Arjmandnia A.A, Shokoohi-Yekta M, HasanZadeh S, MoghaddamZadeh A. Construction and validation of the preliminary version of the pictorial-computer test for executive functions. J of Psychological Science. 2021; 20(104): 1235-1249.

URL: https://psychologicalscience.ir/article-1-1106-fa.html
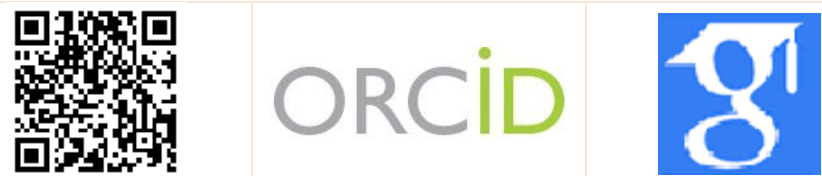

$10.52547 /$ JPS.20.104.1235
A R T I C L E I N F O

Keywords:

executive functions,

updating,

working memory,

shifting,

inhibition

Received: 05 Jan 2021

Accepted: 30 Jan 2021

Available: 23 Oct 2021
A B S T R A C T

Background: Executive functions are a set of high-level cognitive processes that, by influencing low-level processes, enable individuals to direct their thoughts and actions. Despite the importance of measuring executive functions Many current tests of executive function are complex, have limited reliability and validity, and suffer from task impurity.

Aims: The purpose of this project was to develop a novel set of executive function test based on the integrated model of executive function.

Methods: The sample consisted of 115 students (18 girls and 97 boys) who were selected by cluster random sampling from 16 and 6 urban areas of Tehran $(M=9.2$ years; $S D=1.7)$. central nervous system vital signs test was used to evaluate the validity of the test. Pearson correlation tests and exploratory and confirmatory factor analysis were used to analyze the data.

Results: The reliability of the main scores of the subtests was mainly calculated in a significant range $(p<0.05)$. Also, the concurrent validity of the test using the correlation showed a significant correlation. The calculated coefficients for the snake and ladder, gift box, school bag, special route, mannequins, cards, apples, ball and rocket and hands are equal to 0.61 , respectively, 0.53, 0.41, 0.79, $0.54,0.38,0.66,0.60$ and 0.39 . Exploratory factor analysis identified three factors: updating, shifting, and inhibition. The results of confirmatory factor analysis also indicated a good fit of the mode. Conclusion: The pictorial-computer test of executive functions has outstanding features for measuring students' executive functions.

* Corresponding Author: AliAkbar Arjmandnia, Associated Professor, Faculty of Psychology and Educational, University of Tehran, Tehran, Iran.

E-mail: arjmandnia@ut.ac.ir

Tel: (+98) 9369676480

2476-5740/ (C) 2021 The Authors. This is an open access article under the CC BY-NC-ND license

(https://creativecommons.org/licenses/by-nc/4.0/). 


\section{Extended Abstract}

\section{Introduction}

Executive functions are a set of high-level cognitive processes that, by influencing low-level processes, enable individuals to direct their thoughts and actions (Friedman and Miyake, 2017). Over the years, there has been much debate about the nature of executive functions, their components, and the relationship between these components. One of the most important debates is about the Unity or diverse structure of executive functions .Unity means that there is a common element that is the same for all executive components and diversity indicates that there is some uniqueness for each specific executive component (Miyake, et al., 2000).

Various models have been proposed for executive functions, but the integrated model proposed by Miyake et al. (2000) seems to have the most agreement. Miyake et al. (2000) identified three major EFs: updating (working memory), set-shifting, and inhibition, which are moderately related to each other, but are clearly separable. These processes serve different functions for goal-directed behavior. Inhibition is the ability to purposefully hinder adominant, automatic, or prepotent response. Setshifting is an executive process that involves disengaging a set of rules for an irrelevant task and activating rules for an alternate task, and updating $(\mathrm{WM})$ is a limited capacity store that retains information that can be manipulated.

This model can also be used in the field of assessing executive functions. There are numerous neuropsychological tests for assessing executive functions, however the measurement of the construct of executive functioning is challenging on many levels. The first issue concerns the construct of executive functions, models and definitions. They also have limited reliability and validity, and suffer from task impurity, so that different components are involved in performing tasks related to executive function. According to Miyake et al. (2000), some of the problems of impurity and reliability of tools can be reduced by using multiple tasks. In addition, some executive function tests are not applicable to clinical groups. For example, some students with learning disabilities may perform lower than their actual performance due to reading and speech problems.

In accordance with the gaps in the assessment of executive functions, this study intends to reduce the mentioned problems and issues by applying an integrated model of executive functions. The purpose of this project was to develop a novel set of executive function test based on the integrated model of executive function. This test measures the three components of updating, set shifting, and inhibition.

\section{Method}

The sample consisted of 115 students (18 girls and 97 boys) who were selected by cluster random sampling from 16 and 6 urban areas of Tehran (M=9.2 years; $\mathrm{SD}=1.7)$. Criteria for entering the study were: Conscious consent to enter the study, age range 7 to 13 years, having moderate or higher IQ. Exclusion criteria also included: any cognitive or developmental problems, a history of $\mathrm{AD} / \mathrm{HD}$ Disorder, learning disabilities, autism, as well as other behavioral or emotional problems based on student records and statements by school officials.

To develope the test, the background of the current tests was first evaluated, and based on their strengths and weaknesses, various tasks were designed for the three main components. The tasks were evaluated and reviewed in several stages, and finally tasks were approved and provided to a computer expert to prepare a software version. The pictorial-computer test was designed by Rafikhah et al. (2020). This test consists of three components and 9 subtests: 1 . Updating (snake and ladder, gift box, and school bag); 2. Set-shifting (special route, mannequins, and cards); 3. Inhibition (apples, balls and rockets, and hands). The Central Nervous System Vital Signs (CNSVS) was used to evaluate the concurrent validity of the designed test.

\section{Results}

The test-retest method was used to examine the reliability. There is a significant correlation between most of the main scores between the two stages of the test. However, in the card test, there was no significant correlation between Perseverative Errors and Failure to Maintain a Set. Concurrent validity of the test was examined using the correlation between 


\section{Monthly Journal of Psychological Science}

the main scores of subtests and three tests of CNSVS; visual memory, attention shifting, and inhibition with a sample of 30 students (Table 1). The results show that all subtests have a high correlation.

Exploratory and confirmatory factor analysis were used to examine the construct validity. The results showed that the three factors have the highest factor
Vol. 20, No. 104, Autumn(November) 2021

loading. Table 2 shows the matrix of rotated components using the varimax rotation method. Each of the nine subtests has the highest load on its own factor, so that the updating subtests on factor 1 , the set-shifting subtests on factor 2, and the Inhibition subtests on factor 3 (Table 2).

Table 1. Concurrent validity

\begin{tabular}{cclccc}
\hline Visual memory & \multicolumn{3}{c}{ Attention shifting } & \multicolumn{2}{c}{ Inhibition } \\
\hline Snake and ladder & 0.61 & Special route & 0.79 & Apples & -0.66 \\
Gift box & 0.53 & Mannequins & 0.54 & Balls and rockets & -0.60 \\
School bag & 0.41 & Cards & 0.38 & Hands & -0.39 \\
\hline
\end{tabular}

Table 2. Extracted factors

\begin{tabular}{cccc}
\hline & Factor 1 & Factor 2 & Factor 3 \\
\hline Span (Snake and ladder) & 0.74 & 0.05 & -0.44 \\
Span (Gift box) & 0.90 & 0.06 & -0.08 \\
Span (School bag) & 0.84 & 0.14 & 0.13 \\
Shifting score (Special route) & 0.04 & 0.81 & -0.35 \\
Shifting score (Mannequins) & 0.03 & 0.90 & -0.15 \\
Categories (Cards) & 0.07 & 0.80 & -0.05 \\
Interference error (Apples) & -0.27 & 0.05 & 0.72 \\
Stop Signal error (Balls and rockets) & -0.27 & -0.05 & 0.60 \\
Interference error (Hands) & 0.03 & -0.13 & 0.67 \\
\hline
\end{tabular}

Table 3. Analysis of covariance the effect of educational intervention on dependent variables

\begin{tabular}{ccccccc}
\hline Source of changes & Sum of squares & df & Mean square & F & Sig. & Effect size \\
\hline fluid reasoning & 198.17 & 1 & 198.17 & 58.28 & 0.001 & 0.69 \\
verbal comprehension & 93.71 & 1 & 93.71 & 27.08 & 0.001 & 0.51 \\
\hline
\end{tabular}

Confirmatory factor analysis was used to examine the fit of the proposed model. Figure 1 shows that the subtests designed in the three main components have acceptable standard coefficients. Also, RMSEA, GFI, Chi-square CFI, NFI, IFI and AFGI indices showed that the three-component model has a good fit.

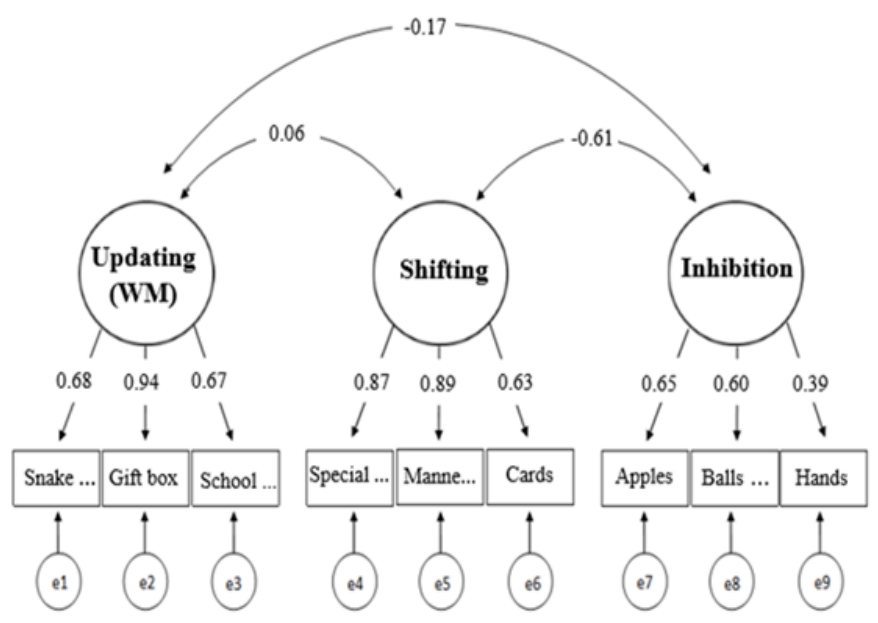

Figure 1. Three-factor model

\section{Conclusion}

In the present study, we tried to design the tasks as much as possible based on theory. The results generally showed that the pictorial-computer test of executive functions has good validity and reliability. It was also found that the three-factor model of executive functions has a good fit (Figure 1), which is consistent with Miyake et al., 2000; Lehto et al., 2003; Wu et al., 2011; Huizinga et al., 2006; McKenna et al., 2017.

This test has important features, for example, the use of several subtests to measure each component of executive functions, the use of meaningful tasks, reducing the impact of other executive and nonexecutive components, applying for students with learning disabilities and also the use of software to run and score the test. 


\section{Psychological Science}

Ethical Considerations

Compliance with ethical guidelines: This article is extracted from the Ph.D. dissertation of the first author at the Faculty of Psychology and Educational Sciences, University of Tehran. All present students participated in the study with informed consent. Ethics codes 1, 2, 3 and 17 (participants' consent and confidentiality of information) are considered in this study.
Vol. 20, No. 104, Autumn(November) 2021

Funding: This study was conducted as a PhD thesis with no financial support.

Authors' contribution: The first author was the senior author, the second and third were the supervisors and the fourth and fifth were the advisors.

Conflict of interest: the authors declare no conflict of interest for this study.

Acknowledgments: I would like to appreciate the supervisor, the advisors, and the participants in the study. 


\section{ساخت و اعتباريابى نسخه مقدماتى آزمون تصويرى - رايانهاى كار كردهاى اجرايى}

\section{محسن رفيع خواه'، على اكبر ارجمندنيا"، محسن شكوهى يكتا'، سعيد حسنزاده'، على مقدمزادهء}

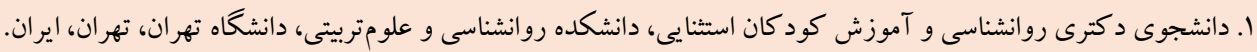

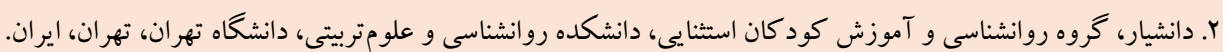

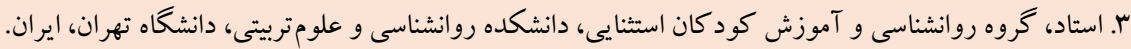

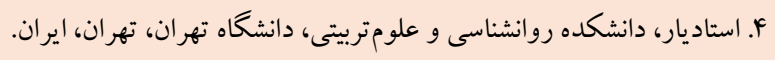

جكيده

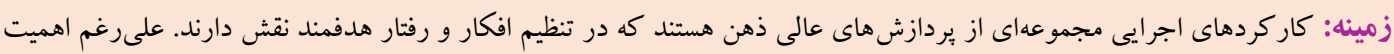

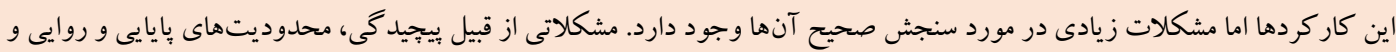
همجينين ناخالصى در سنجش مؤلفهها. هدف: اين يُوهش با هدف ساخت و اعتباريابى آزمون تصويرى - رايانهاى كاركردهاى اجرايى انجام بذيرفت تا مشكلات موجود در ابزارهاى رايج را به حداقل برساند.

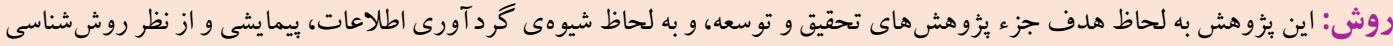

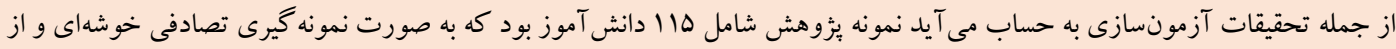
مناطق 19 و 4 شهرى تهران انتخاب شدند. از آزمون علائم حياتى سيستم اعصاب مر كزى به عنوان اندان ابزارى جهت تعيين روايى همز مان استفاده

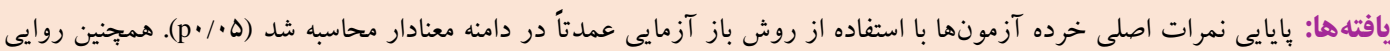

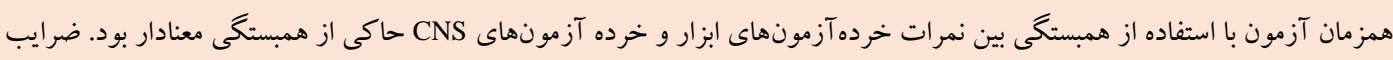

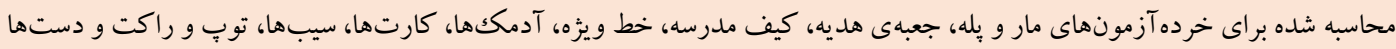

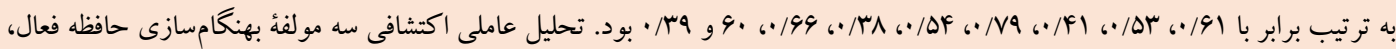

$$
\text { جابه جايى ذهنى و بازدارى را شناسايى كرد. }
$$

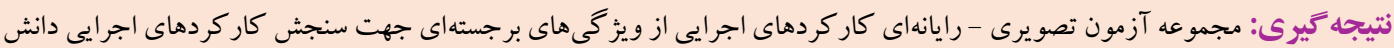
آموزان برخوردار است.
مشخصات مقاله

كليدواثهها: كاركردهاى اجرايى،

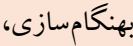
حافظه فعال، جابه جايى ذهنى، بازدارى

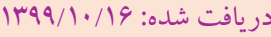

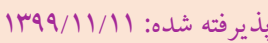

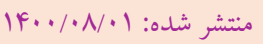

* نويسنده مسئول: على اكبر ارجمندنيا، دانشيار، گروه روانشناسى و آموزش كود كان استثنيى، دانشكده روانشناسى و علومترييت، دانشخاه تهران، تهران، ايران. رايانامه: arjmandnia@ut.ac.ir 


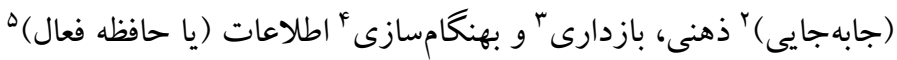

dollo

هستند.

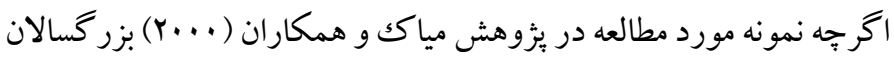

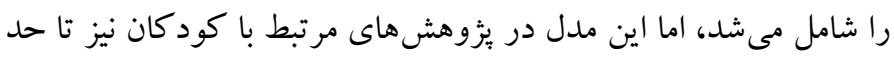

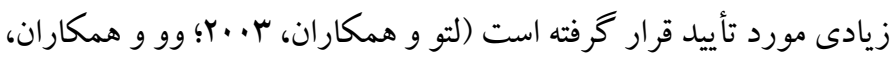

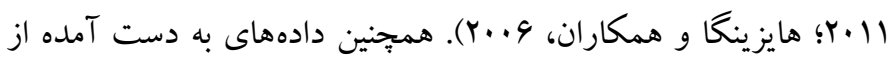

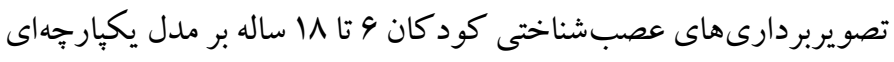

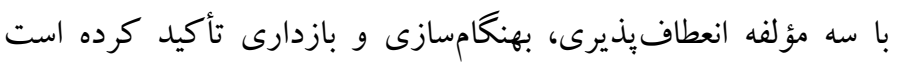

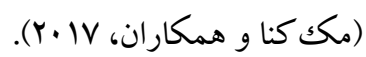

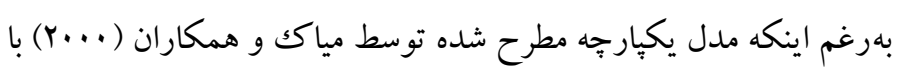
ادغام كردن مدلهاى بيشين از حمايت زيادى برخوردار است اما همجِنان

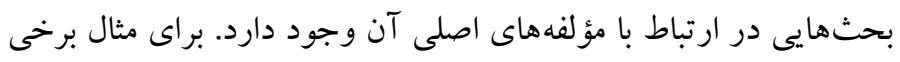

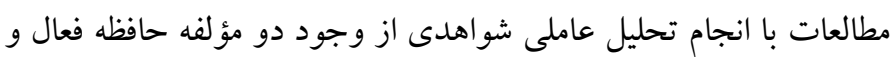
انعطاف يذيرى گز ارش كردهاند اما در شناسايى مؤلفه سوم (بازدارى) ناكام

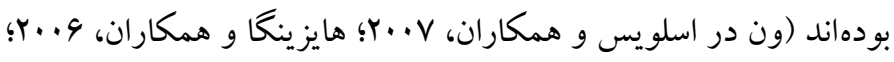

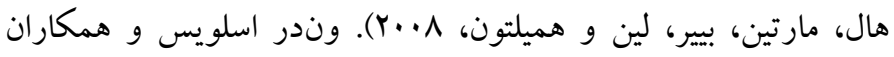

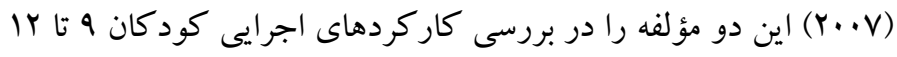
سال شناسايى كردند. آنان همجنين با استفاده از تكاليفى كه واريانس آنها دورديا

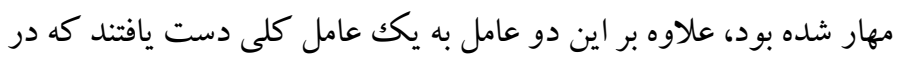
بين تمامى تكاليف داراى بار عاملى بود.

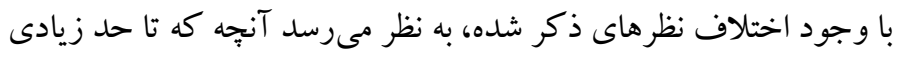

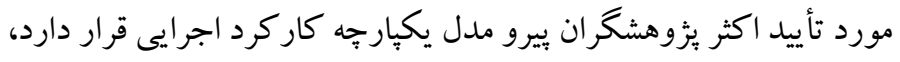

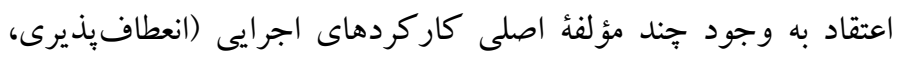
حافظه فعال / بهنگامسازى و بازدارى) است. نقص در اين مؤلفه ها همجينين در بسيارى از اختلالهاى رشدى نيز مشاهده مىشود.

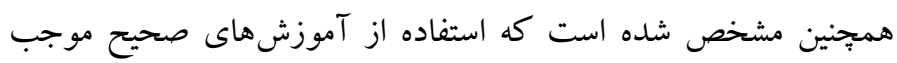

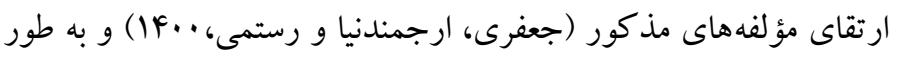
كلى كاركردهاى اجرايى مىشود (شكوهىيكتا، زمانى، بور كريمى و و

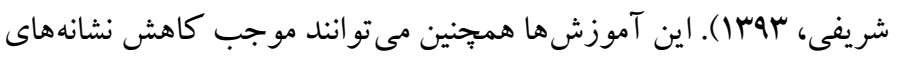
اختلال در نارسايى هاى رشدى شوند ( قاسمى، كجباف، قمر انى، تر كان،

4. Updating

5 . Working Memory
كار كردهاى اجر ايى' مجموعه فر آيندهاى شناختى سطح بالاى مغز هستند

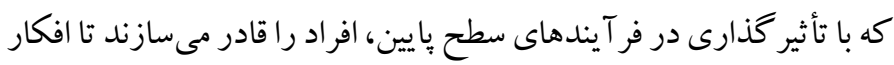

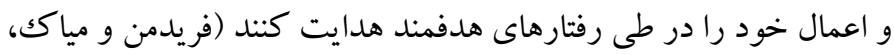

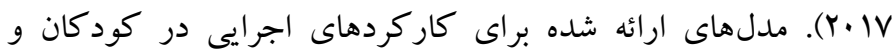

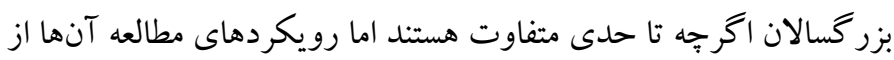

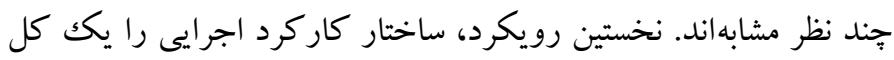

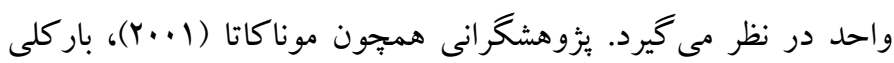

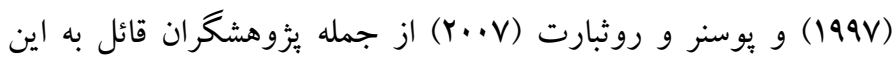
رويكرد هستند. براى مثال يوسنر و روثبارت (Y.V.V) در مطالعه كود كان

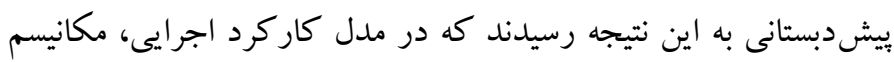

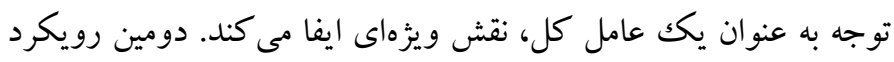

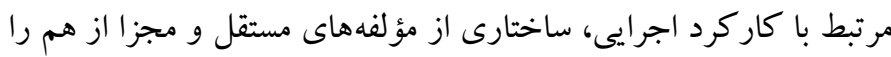
يشنهاد مى كند كه مسير تحولى متفاوتى از يكديخر دارند (دياموند،

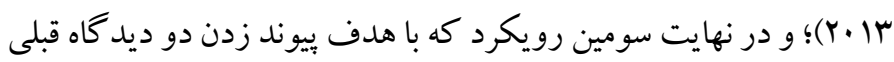

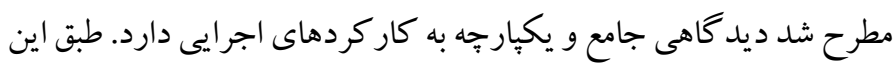
رويكرد، كار كرد اجر ايى دربر گيرندهى مؤلفههايى است كه نسبتاً مستقل از

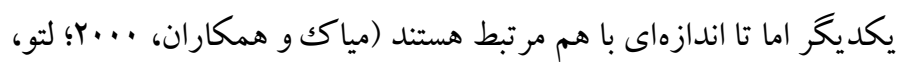

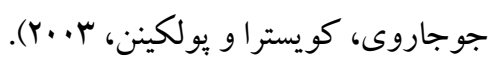

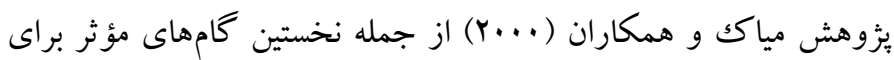

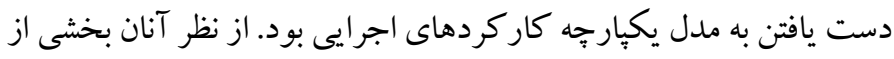
دشوارى ارزيابى مؤلفههاى كاركرد اجر ايى به اين علت است كه اندازه

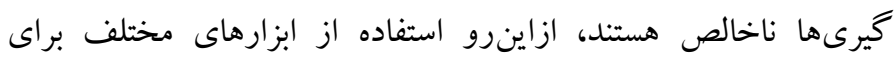

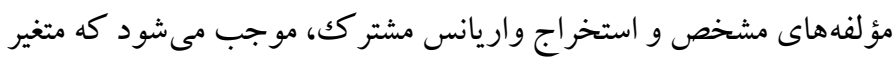

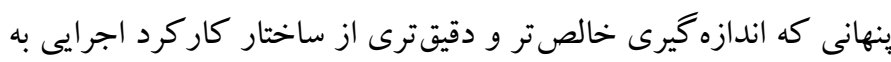
دست مىدهد، حاصل شود. مياك و همكاران (Y..... با استفاده از تحليل عاملى، ابزارهاى مختلف سنجش كار كردهاى اجر ايى را مورد بررسى قرار

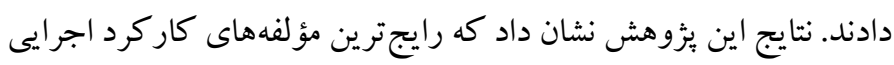

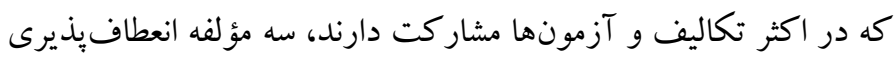

1. Executive function

2. Set-shifting

3 . Inhibition 
- آيا خرده آزمونهاى طراحى شده براى مؤلفهُ حافظه فعال از روايى و

$$
\text { يايايى مناسب برخوردارند؟ }
$$

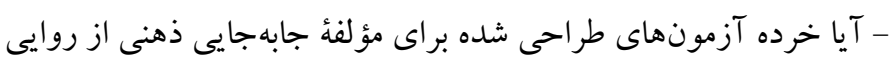

$$
\text { و بايايى مناسب برخوردارند؟ }
$$

- آيا خرده آزمونهاى طراحى شده براى مؤلفؤ بازدارى از روايى و بايايى

$$
\text { مناسب برخوردارند؟ }
$$

شايان ذكر است كه آزمون طراحى شده در بستر رايانه اجرا مى گردد كه اين امر علاوه بر ايجاد جذابيت براى شركت كنندكان، فرايند اجرا و ونمره

$$
\text { دهى را تسهيل خواهد كرد. }
$$

روش

الف) طرح بثوهش و شركت كنند كان: ئزوهش حاضر از نظر هدف بنيادى - كاربردى و از حيث نوع گردآورى اطلاعات بيمايشى و از نظر روششناسى از جمله مطالعات آزمونسازى به حساب مى آيد كه در قالب

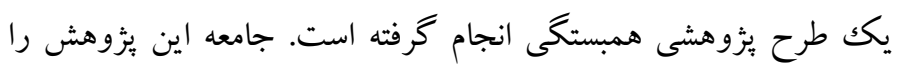

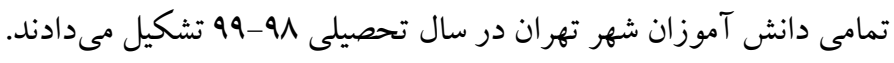

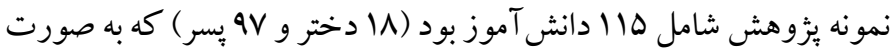
نمونه گيرى تصادفى خوشهاى و از مناطق 19 و 4 شهرى تهران انتخاب

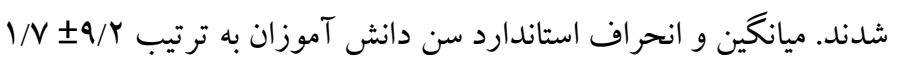
محاسبه شد. ملاككهاى ورود به يُزوهش براى اين دانش آموزان عبارت

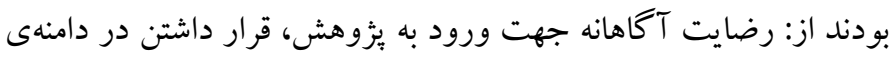
سنى V تا سا سال، برخوردارى از بهره هوشى متوسط و يا بالاتر. ملاكك هاى

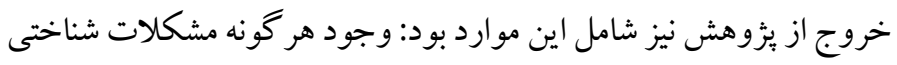

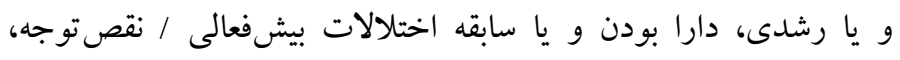
اختلالات ياد گيرى، اوتيسم و همجنين مشكلات رفتارى يا هيجانى ديخر

$$
\text { بر اساس برونده دانش آموز و اظهارات مسئولين مدارس. }
$$

روش اجراى بزٔوهش به اين صورت بود كه ابتدا با مطالعه بيشينه ابزارهاى

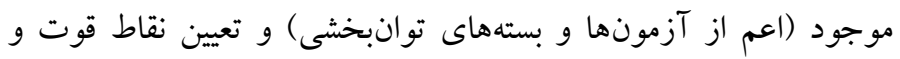

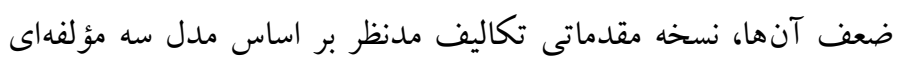

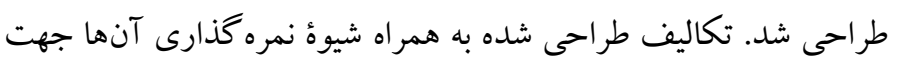
تعيين بررسى اوليه در اختيار ه نفر از اساتيد متخصص دانشكاه تهران و
9911). بديهى است كه آموزش و ارتقاى كار كردهاى اجر ايى بيش از هر جيز مستلزم ارزيابى و سنجش صحيح است اما جند مسئله اساسى در ارتباط

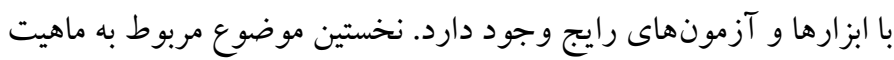

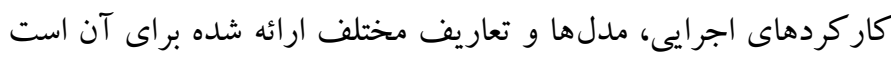

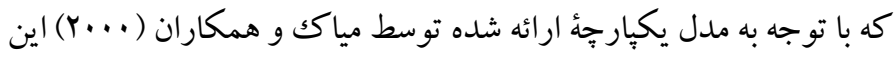

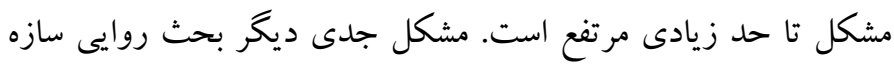

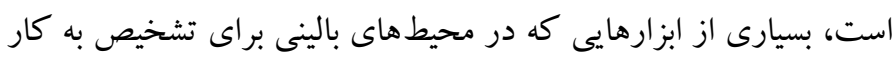

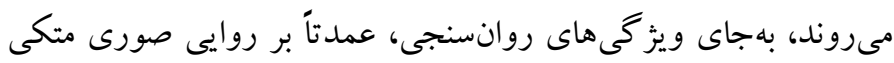

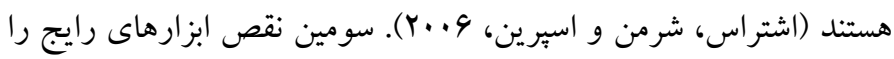

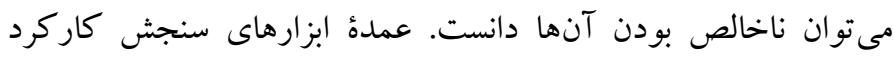

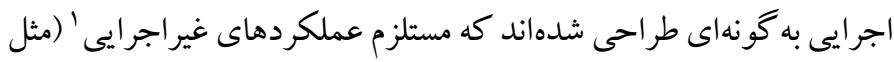
توانيى كلامى، توانايى خواندن، سرعت و...) هستند (ون در اسلويس و و

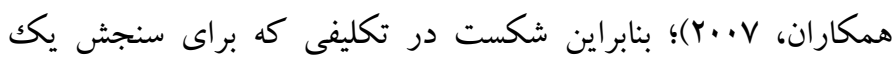

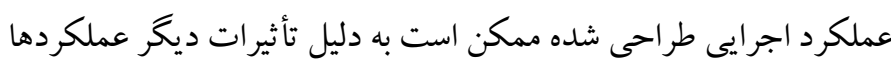

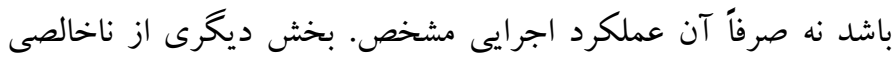
ابزارهاى سنجش كاركردهاى اجرايى از تعامل بين مؤلفههاى كاركرد

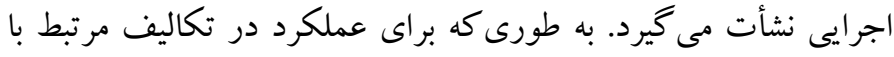

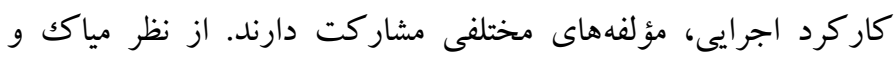

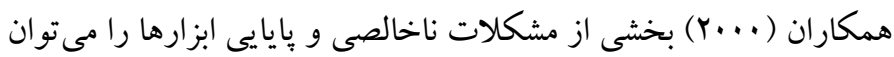

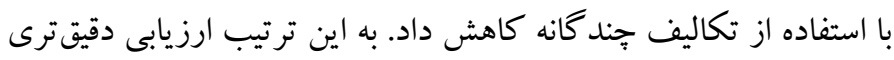

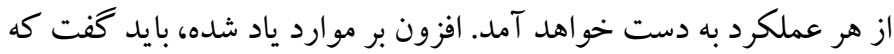
استفاده از ابزارهاى سنجش براى برخى از گروههاى دجهار اختلالهاى

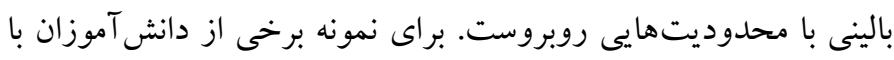

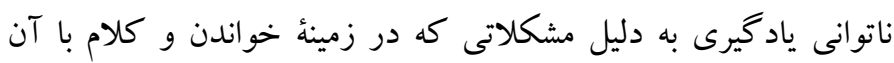

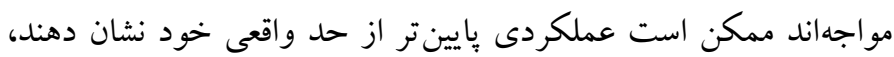

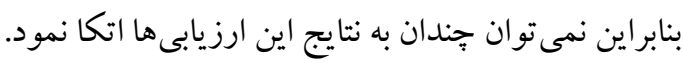

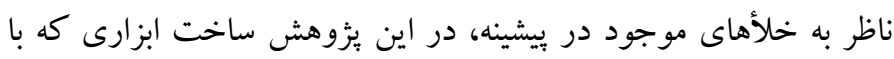

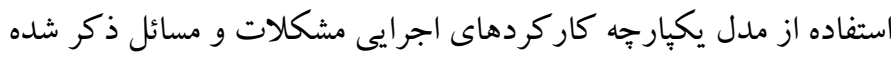

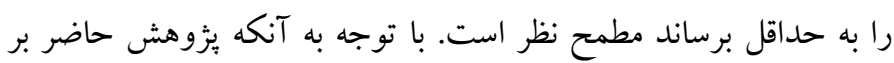
اساس مدل سه مؤلفهاى حافظه فعال، جابهجايى ذهنى و بازدارى طراحى

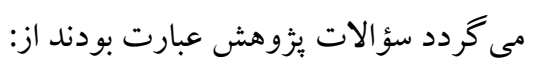


هديه، جعبه مذكور به عنوان جعبهُ خالى قلمداد شده و بنابر اين در نمايش دوم نبايد انتخاب شود. وجه تمايز اين آزمون اين است كه علاوه بر دو نمرة

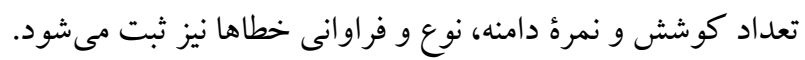

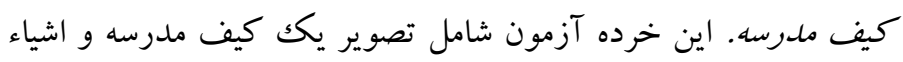

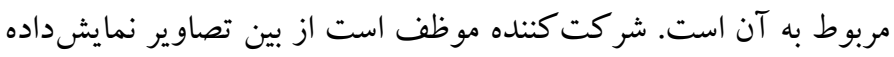
شده، اشيائى كه داخل يا بيرون از كيف قرار دارند را ارزيابى كرده و در نهايت تصاوير داخل كيف را انتخاب نمايد.

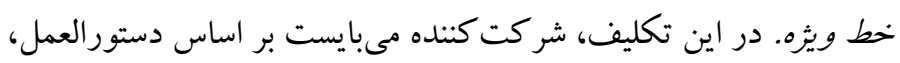

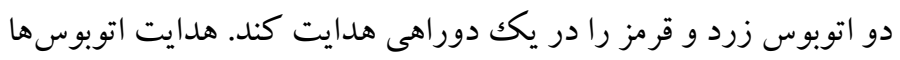
بر اساس علامتى است كه در مسير اصلى قرار دارد و بهطور تصادفى به رنگك قرمز يا زرد درمى آيد. با اين حال يكك استثنا وجود دارد و آن زمانى است كه يكك آمبولانس در يشت اتوبوس قرار دارد. در اين حالت هميشه آمبولانس بهجاى اتوبوس در مسير اصلى قرار مى گيرد. آدمككها. در خرده آزمون آدمككها جابهجايى ذهنى با استفاده از جهار

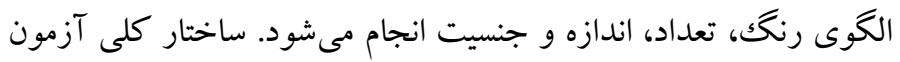
شامل دو تصوير از آدمككهاست كه در سمت راست و جٍِ صفحه قرار كرفتهاند. تكليف شر كت كننده اين است كه ديخر آدمك هاى نمايش داده

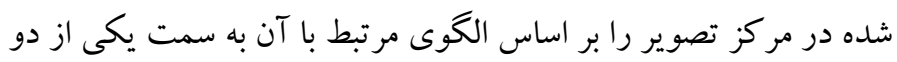
تصوير اصلى هدايت كند. كارتها. اين خرده آزمون اقتباسى از آزمون مرتب كردن كارته هاى ويسكانسين و شامل DF كارت است كه سه كارت به صورت ثابت در مركز تصوير قرار دارند. وظيفه شركت كننده اين است كه ديخر كارتها را بر

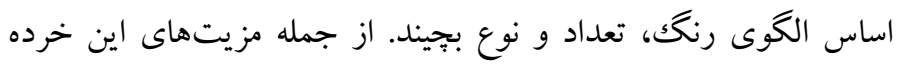
آزمون نسبت به آزمون ويسكانسين مهار كردن مؤلفه حافظه فعال است. به اين صورت كه كارتهايى كه به درستى انتخاب شدهاند در بالاى كارت

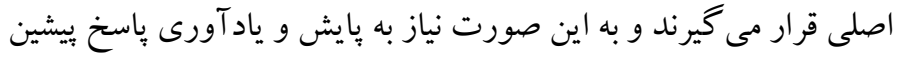

سيبها. اين خرده آزمون متشكل از VIV دايره است كه در مركز آنها تصوير يكك سيب قرمز رنگك به صورت ثابت قرار دارد كه در واقع الكو و دستور العمل آزمون است. دو سيب ديخر به رنگگهاى زرد و و سبز در اين

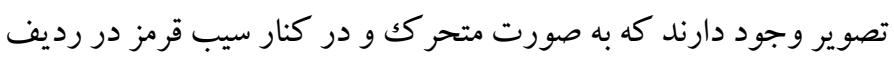
ها يا ستونهاى سه تايى به نمايش در مى آيند. شر كت كننده بايد در هنگام
دانشكاه علوم بهزيستى و توانبخشى قرار كرفت. در اين مرحله سؤالاتى در رابطه با مناسب بودن خرده آزمونها و تناسب آنها با مؤلفههاى مدنظر،

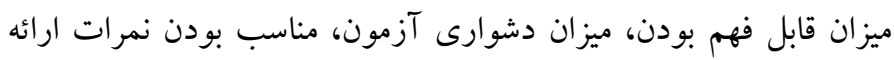

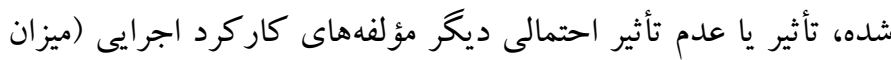

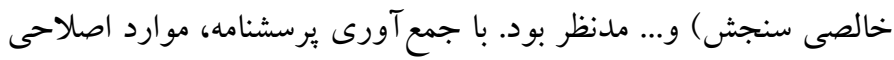

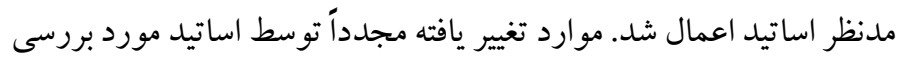

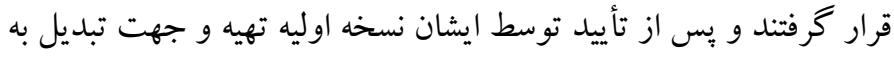
نرمافزار آماده شد.

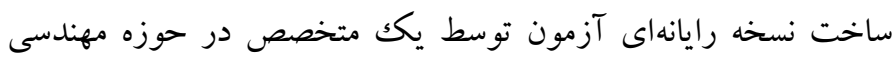
نرمافزار انجام شد. اين نسخه پِ از ساخت و ارزيابى ابتدايى، به صورت بايلوت بر روى •ا دانش آموز با سنين مختلف انجام شد. در اين مرحله

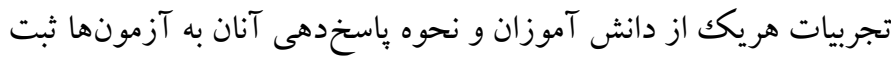

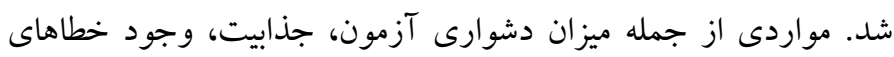

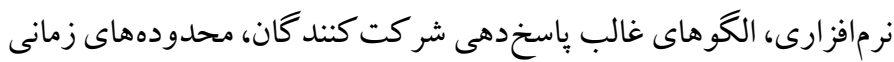

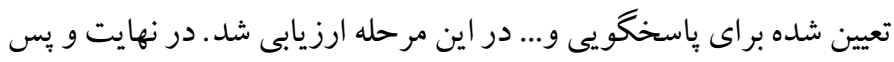
از جند مر حله بازبينى و رفع خطاهاى نرم افزارى نسخه نهايى آزمون طر احى ندي

شل. معرفى آزمون آزمون تصويرى - رايانهاى كار كردهاى اجرايى مشتمل بر سه مؤلفه و نه

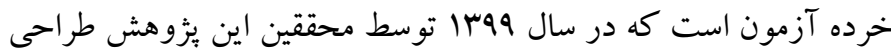
شده است. مؤلفهاى مورد سنجش و عناوين خرده آزمونها عبارتند از:

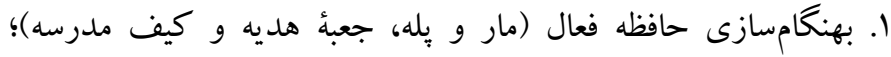

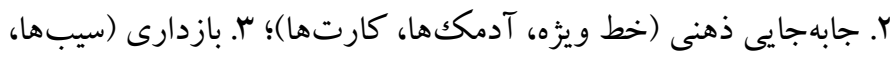

$$
\text { توبٍ و راكت، دستها). }
$$

مار و بِله. در اين تكليف شركت كننده مىبايست بر روى تاسهايى كه به

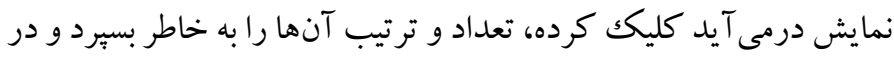

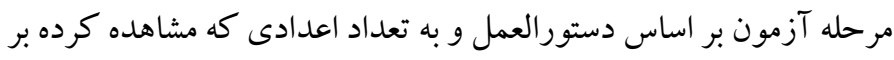
روى صفحه مارييج حر كت كند. جعبة هلديه. وظيفه شركت كننده در اين تكليف اين است كه در مرحلة

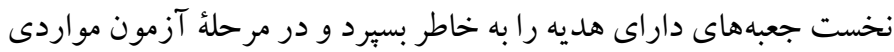
كه داراى هديه بودند را بازشناسى كند. به شر كت كنند گان تأكيد مى شود كه هر جعبة داراى هديه فقط يككبار بايد انتخاب شود و پِّ از مشاهدة 
قرار گرفتن سيب قرمز مابين دو سيب ديخر دكمه فاصلهاند از (اسبيس) را يافته ها

نمرات توصيفى هر يكك از نه خرده آزمون در جدول اقابل مشاهده است.

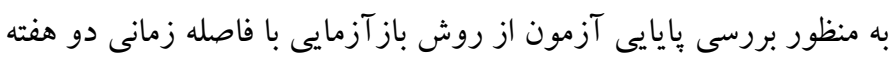

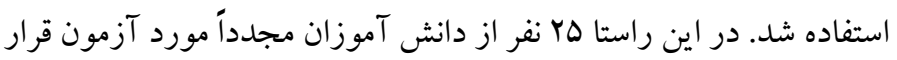

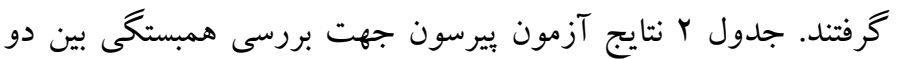
مر حله آزمون را به تفكيك ب مؤلفئ اصلى نشان مى دهند.

\begin{tabular}{|c|c|c|c|c|}
\hline ميانگين (انحر افتاف & بيشترين & كمترين & 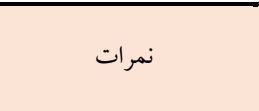 & آزمونها \\
\hline$(I / \cdot Y) r / I V$ & 9 & $r$ & 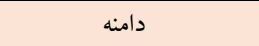 & \multirow{3}{*}{ مار و يُه } \\
\hline$(1 / 91) \Delta / \kappa \mu$ & 11 & r & كوشش صحيح & \\
\hline$(1 / .9) r / 4$. & 9 & r & دامنه & \\
\hline$(1 / \wedge V) \Delta / A r$ & 1. & r & كوشش صحيح & \multirow{4}{*}{ جعبة هديه } \\
\hline$(1 / 10) 1 / / 49$ & f & · & خطاى انتخاب & \\
\hline$(1 / K Y) I / F Y$ & $\Delta$ & · & خطاى حذف & \\
\hline$(1 / r \Delta) r / \cdot F$ & 9 & . & خطاى تكرار & \\
\hline$(1 / r V) r / \Delta$. & $\wedge$ & r & دامنه & كيف \\
\hline$(Y / T Y) V / \Delta q$ & ir & $r$ & كوشش صحيح & مدرسه \\
\hline$(9 / 91)$ FV/Qr & 4. & r & "ِاسخ صحيح & \multirow{6}{*}{ خط ويزه } \\
\hline$(F / \Delta 1) V / V q$ & r. & . & ياسخ اشتباه & \\
\hline$(r / \Lambda \cdot) F / \Lambda r$ & If & . & ياسخ ازدستر فته & \\
\hline$(r / \mid V)|F / F|$ & r. & $\wedge$ & نمرءٔ جابهجايى & \\
\hline$($ TYF/MM)199./YO & rorl & $\wedge$ ^. & زمان واكنش (جابهجايى) & \\
\hline$($ YVN/DI) $) \Delta Y / V$. & rrVG & QqT & زمان واكنش (عادى) & \\
\hline$(V / V \Delta) \& \& / \Lambda$. & 91 & rV & هاسخ صحيح & \multirow{5}{*}{ آدمككها } \\
\hline$(\Delta / Q Y) \| 1 / \Delta \Delta$ & rV & r & ياسخ اشتباه & \\
\hline$(r / A r) \Delta / 9 V$ & r. & . & پِاسخ از دست رفته & \\
\hline$(\mid Y / M F) V Y / A V$ & 90 & Fr & نمره جابهجايى & \\
\hline$(r \cdot r / \mid r) \mid V \cdot \Delta / 11$ & rar. & $1 . \mathrm{Y4}$ & زمان واكنش & \\
\hline$(\mathrm{I} / \mathrm{IV}) \mathrm{Y} / \mathrm{AV}$ & 9 & 1 & طبقات & \multirow{6}{*}{ كارتها } \\
\hline$(\Lambda / \cdot V) r \mathrm{~V} / 9 \mathrm{~V}$ & FA & 11 & ياسخ صحيح & \\
\hline$(\Lambda / 11) Y Y / Y Y$ & rq & 9 & ي ״ِاسخ اشتباه & \\
\hline$(\cdot / r \Delta) \Delta r / q F$ & $\Delta F$ & $\Delta 1$ & كل بِاسخها & \\
\hline$(\Delta / \wedge \varphi) \Lambda / \Gamma)$ & YF & · & خطاى درجاماندگى & \\
\hline$(1 / r q) r / \cdot F$ & 9 & · & شكست در حفظتوالى & \\
\hline$(r / \Gamma \Delta) \Lambda / \Lambda l$ & 11 & $r$ & خطاى ارتكاب & \multirow{5}{*}{ سيبها } \\
\hline$(1 / \Delta 4) Y / V^{F}$ & 9 & . & پِاسخ از دست رفته & \\
\hline$(1 / 99) r / \Gamma \Lambda$ & 9 & . & خطاى تداخل & \\
\hline$(\mathrm{V} / \mathrm{g} \cdot 9) \mathrm{raq} / \mathrm{Al}$ & FAF & rrr & زمان واكنش (ساده) & \\
\hline$(9 N / r I) F \cdot \Delta / 9 r$ & FqD & TFV & زمان واكنش (ييجِيده) & \\
\hline
\end{tabular}

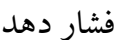

توبٍ و راكت. اين آزمون اقتباسى از الكوى آزمون نشانه توقف است كه

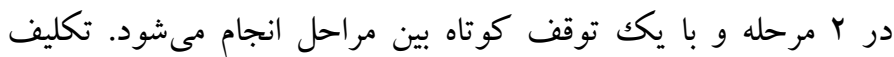

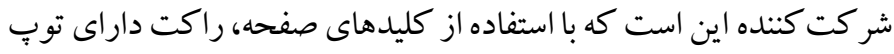

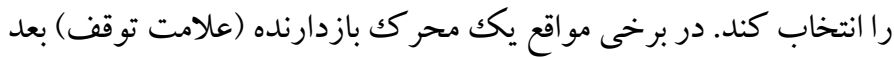

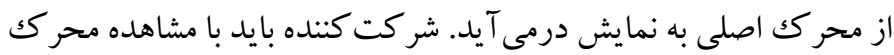

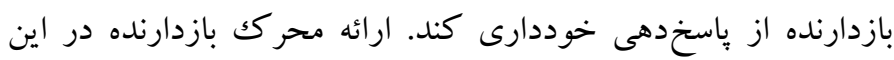

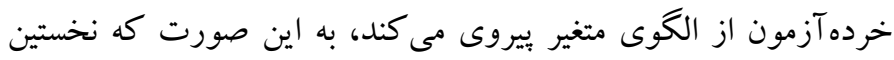

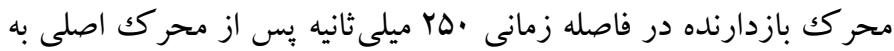
نمايش درمى آيد و موفقيت شركت كننده موجب افزايش ·ه ميلى ثانيهاى

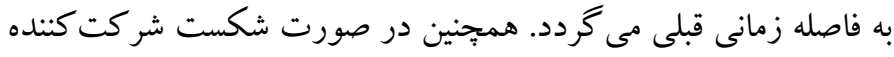

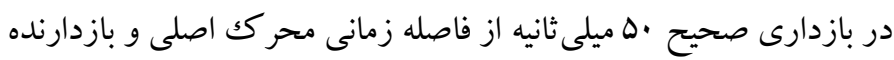
كاسته مى شود. دستها. ساختار كلى آزمون شامل تصوير يكك دست است كه به يكى از جهار جهت جִب، راست، بالاو يا پِايين اشاره كرده است. تكليف شركت كننده در اين آزمون توجه كردن به مسير حركتى دستهايى است كه به به به به بـ نمايش درمى آيند نه جهتى كه به آن اشاره مى كنند.

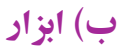
آزمون علائم حياتى سيستم اعصاب مر كزى (CNSVS): اين آزمون عصب

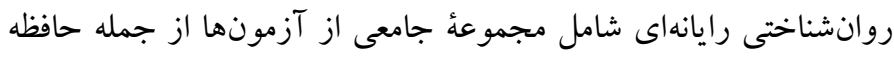

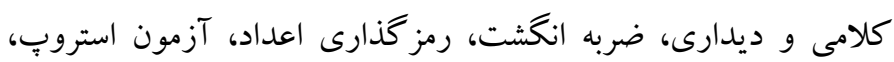

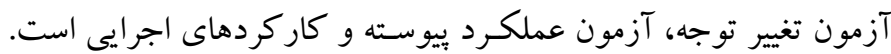

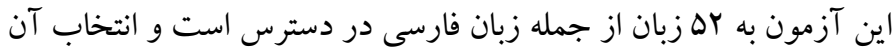
در يزو هش حاضر در وهله نخست به دليل وجود سه مؤلفهُ حافظه تصويرى،

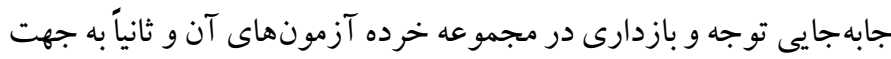
اجراى رايانهاى آن صورت يذيرفت. هنجاريابى اين آزمون توسط كالتيرى

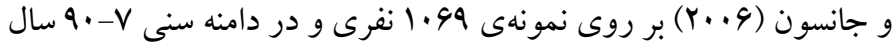
انجام شده است. بايايى آزمون در تمامى تكاليف مناسب و در سطح كمتر از هل صدم معنادار گز ارش شده است. 
نمره خطاى درجاماندكى و شكست در حفظ توالى با وجود آنكه جزء نمرات اصلى هستند اما همبستكى معنادارى در دو مرحله نشان ندادند. بهطور كلى مى توان اظهار داشت كه با توجه به نمرات اصلى خرده آزمون ها، يايايى آزمون تأييد مى شود. بررسى روايى همزمان آزمون با استفاده از همبستگى بين نمرات اصلى خرده آزمونهاى حاضر با سه خرده آزمون حافظه تصويرى، جابهجايى توجه و بازدارى از مجموعه آزمون علائم حياتى سيستم اعصاب مركزى و با نمونهاى مشتمل بر .ب نفر انجام شد (جدول ץ). اين جدول نشان مى دهد كه تمامى خرده آزمونها از همبستكى بالايى برخوردارند، در نتيجه روايى همزمان آزمون تأييد مىشود. لازم به ذكر است كه ضريب همبستكى منفى در خرده آزمونهاى بازدارى به اين دليل است كه از نمرات خطاى خرده آزمونهاى كاركرد اجر ايى استفاده

شده است.

\begin{tabular}{|c|c|c|c|c|}
\hline ميانگين (انحراف & بيشترين & كمترين & 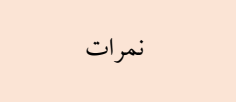 & خردهه \\
\hline$(9 / 94) 91 / 91$ & 110 & 99 & ياسخ صحيح & \multirow{7}{*}{ توبَ و } \\
\hline$(1 / 19) 1 / 94$ & f & . & خطاى جهت & \\
\hline$(9 / \Gamma \cdot) q / 1 \Lambda$ & YA & 1 & يِاسخ از دست رفته & \\
\hline$(8 / I V) I Q / Y V$ & r. & $r$ & خطاى نشانه توقف & \\
\hline$(\Lambda V / \cdot r) \wedge r q / \Delta \varphi$ & $11 . r$ & gra & زمان واكنش صحيح & \\
\hline$(\Lambda r / q \mu) F F I / q 1$ & GTS & ro. & زمان تأخير نشانه توقف & \\
\hline$(11 \cdot / N Y) F / F / \Delta$. & VDr & If. & زمان واكنش نشانه توقف & \\
\hline$(1 / F V) Y q / 91$ & rr & rq & ياسخ صحيح & \multirow{5}{*}{ دستها } \\
\hline$(1 / \cdot \Lambda) 1 / f \Delta$ & f & · & ياسخ از دست رفته & \\
\hline$(\cdot / \wedge ৭) \cdot / ৭$ & $r$ & . & خطاى تداخل & \\
\hline$(|F T / A|)|F| F / Q q$ & 1919 & $1.9 r$ & زمان واكنش (ساده) & \\
\hline$(\mid Y \cdot / \cdot Y) \backslash F r G / T V$ & 1911 & 1111 & زمان واكنش (يِجيده) & \\
\hline
\end{tabular}

همانطور كه جدول r نشان ميدهد در اكثر نمرات اصلى بين دو مرحله آزمون همبستكى معنادارى وجود دارد. تنها در خرده آزمون كارت ها، دو

جدول r. نتايج آزمون بيرسون براى دو مرحله اجراى آزمون

\begin{tabular}{|c|c|c|c|c|c|c|c|c|}
\hline & 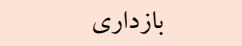 & & & جابهجايى ذهنى & & & حافظه فعال & \\
\hline $\mathrm{r}$ & 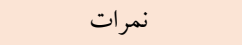 & تكليف & $\mathrm{r}$ & 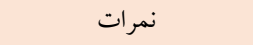 & تكليف & $\mathrm{r}$ & 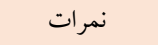 & تكليف \\
\hline$\cdot 19 \mu^{* *}$ & خطاى ارتكاب & & $\cdot / 0 \cdot * *$ & هياسخ صحيح & & $\cdot / 4 F^{*}$ & دامنه & th \\
\hline$\cdot / 99^{* *}$ & يِاسخ ازدسترفته & & 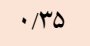 & ي پِاسخ اشتباه & & $\cdot / \& q^{*}$ & كوشش & . \\
\hline$\cdot / \Delta r^{* * *}$ & خطاى تداخل & سيبها & $\cdot / 49$ & باسخ ازدسترفته & خط & $\cdot / 44^{*}$ & دامنه & \\
\hline$-\cdot / \cdot V$ & زمان واكنش (ساده) & & $\cdot / V^{* *}$ & نمره جابهجايى & ويزه ا & $\cdot / 4 \cdot *$ & كوشش & \\
\hline.$- / .9$ & زمان واكنش (ييجتيده) & & $\cdot / 1 \Lambda$ & زمان واكنش (جابهجايى) & &.$/ \cdot 1$ & خطاى انتخاب & جعبة هديه \\
\hline$\cdot 194^{* *}$ & هاسخ صحيح & & $-\cdot / 44$ & زمان واكنش (عادى) & & $\cdot / \cdot v$ & خطاى حذف & \\
\hline.$/ 19$ & خطاى جهت & & $\cdot / \Delta \Delta^{* *}$ & پِاسخ صحيح & & $\cdot / \mu$ & خطاى تكرار & \\
\hline$\cdot / \kappa \mu^{*}$ & ياسخ از دست رفته & & $\cdot / 4 \cdot *$ & ياسخ اشتباه & & $\cdot / 4 r^{*}$ & دامنه & كيف \\
\hline$\cdot / \Delta \Lambda^{* *}$ & خطاى نشانه توقف & נراكت & $\cdot / 11$ & ياسخ از دست رفته & آدمككها & $\cdot / 4 \cdot *$ & كوشش & 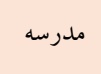 \\
\hline$\cdot / 4 \wedge^{*}$ & زمان واكنش صحيح & & $\cdot / 9 \Lambda^{* *}$ & نمره جابهجايى & & & & \\
\hline$\cdot / 9 \Lambda^{* *}$ & زمان تأخير نشانه توقف & & $\cdot / 1 \wedge$ & زمان واكنش & & & & \\
\hline$\cdot|9|^{* *}$ & زمان واكنش نشانه توقف & & $\cdot / 4 q^{*}$ & طبقات & & & & \\
\hline$\cdot / 19$ & پياسخ صحيح & & $\cdot / \kappa r^{*}$ & ياسخ صحيح & & & & \\
\hline$\cdot / r r$ & پاسخ ازدسترفته & &.$/ 44^{*}$ & هِاسخ اشتباه & كارتها & & & \\
\hline$\left.\cdot|\psi| *\right|^{*}$ & خطاى تداخل & دستها & $\cdot / 19$ & خطاى درجاماندگى & & & & \\
\hline$-\cdot / \cdot 1$ & زمان واكنش (ساده) & & $\cdot / I V$ & شكست در حفظتوالى & & & & \\
\hline$\cdot / \cdot 1$ & زمان واكنش (ييججيده) & & & & & & & \\
\hline
\end{tabular}


حجم نمونه است. همجنين از آزمون بارتلت جهت بررسى ميز ان همبستخى كافى بين دادهها استفاده شد. عدد محاسبه شده براى اين آزمون برابر با بال

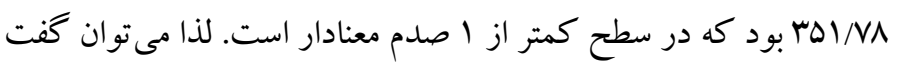
مفروضة وجود همبستكى كافى بين دادهها برقرار است.

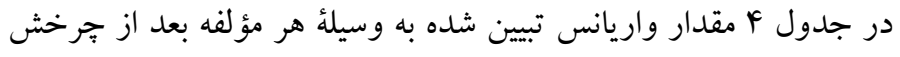

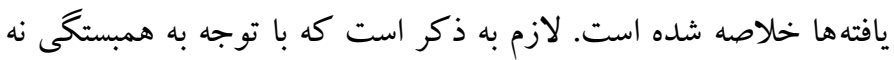
جندان زياد بين دادهها، از فرمان جرخش واريمكس استفاده شده است. همانطور كه مشخص است نه مؤلفه شناسايى شدهاند كه ... واريانس را تبيين مى كنند. ييش فرضى كه اجازه داريم اين تحليل را مطابق با آن انجام دهيم شامل مؤلفه هايى است كه ارزش ويزهى آنها ا يا بالاتر

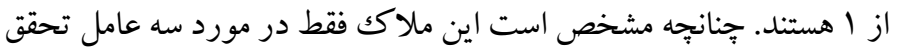
يافته است. اين سه عامل بر روى هم حدود 91 درصد واريانس را تبين مى كنند.
به منظور بررسى روايى سازه از تحليل عاملى اكتشافى با روش تحليل

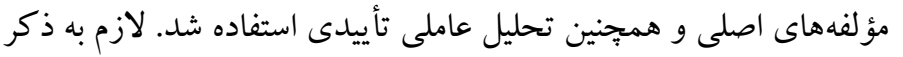

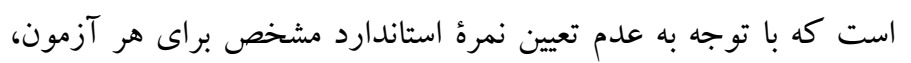

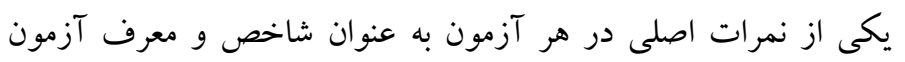

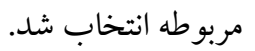
جدول r. نتايج بروسى همبستغى با آزمون CNSVS

\begin{tabular}{|c|c|c|c|c|c|}
\hline \multicolumn{2}{|c|}{ بازدارى CNSVS } & \multicolumn{2}{|c|}{ جابهجايىCNSVS } & \multicolumn{2}{|c|}{ حافظه CNSVS } \\
\hline$-\cdot 194^{* *}$ & سيبها & $\cdot / q^{* *}$ & خط ويزه & $.191 * *$ & مار و يله \\
\hline$-\cdot 19 \cdot * *$ & توب و راكت & $\cdot / \Delta \varphi^{* *}$ & آدمككها & $\cdot / \Delta r^{* *}$ & جعبة هديه \\
\hline$-\cdot / q^{* * *}$ & دستها & $\cdot / \mathrm{N}^{*}$ & كارتها & $\cdot|F|^{*}$ & كيف \\
\hline
\end{tabular}

ييش از انجام تحليل، از آزمونهاى كيزر-ماير-الكين و بارتلت جهت بررسى تناسب اولئ دادهها استفاده شد. آزمون كيزر-ماير -الكين كفايت

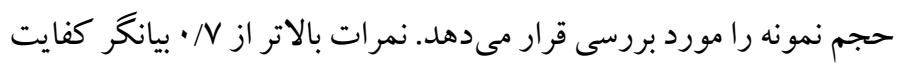

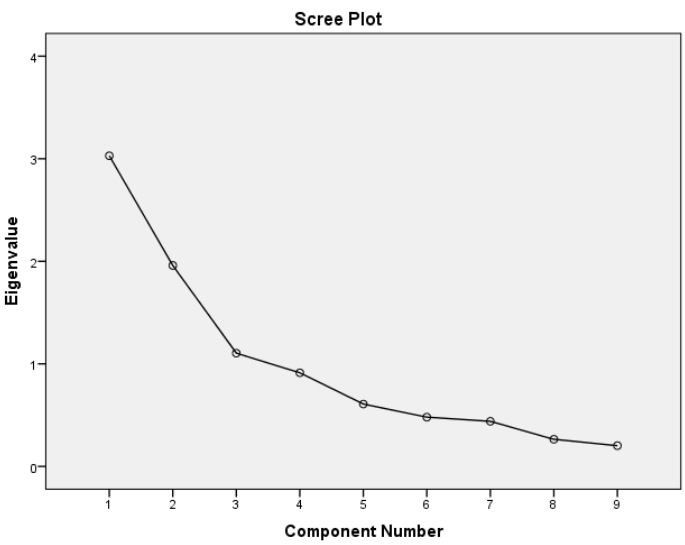

شكل ا. نمودار سنكَريزه براى شناسايى عاملهاى مستخرج
شكل ا نمودار سنگكريزه مربوط به راهحل اوليه را نشان مىدهد. همانطور

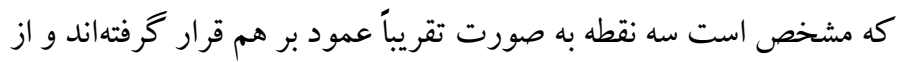

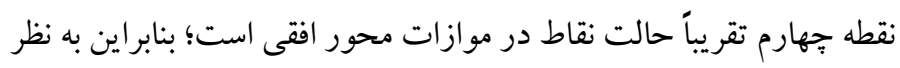
مىرسد اين نمودار نيز راه حل سه مؤلفهاى را تأييد مى كند. 


\begin{tabular}{|c|c|c|}
\hline آستانه يذيرش & مدل & \\
\hline- & $F F / \mu r$ & $\mathrm{X} 2$ \\
\hline- & rF & df \\
\hline$<r$ & I/AF & $\mathrm{X} 2 / \mathrm{df}$ \\
\hline$\geq \cdot / 9$. & $\cdot / 9 F$ & CFI \\
\hline 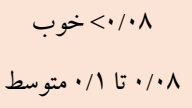 & $\cdot / \cdot \wedge$ & RMSEA \\
\hline$\geq \cdot 19$. & $\cdot / 9 F$ & IFI \\
\hline$\geq \cdot / 9$. & $\cdot / 9$ & NFI \\
\hline$>\cdot / A$. & $\cdot / 19$ & AGFI \\
\hline$\geq \cdot / 9$. & . /9Y & GFI \\
\hline
\end{tabular}

از شاخصهاى برازش مطلق شاخص ريشه خطاى ميانخين مجذورات تقريب (RMSEA)، شاخص نيكويى برازش (GFI) و خیىدو در دامنه

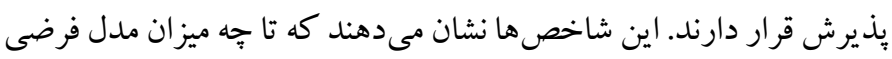
بيشنهادى شبيه مدل مشاهدات است. علاوه بر اين شاخصدهاى برازش

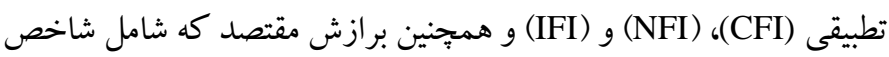
تعديل يافته نيكويى برازش (AGFI) است در دامنه يذيرش قرار دارند.

\section{بحث و نتيجه تيرى}

مجموعه آزمون طراحى شده مبتنى بر نظريه و شامل نه خرده آزمون است

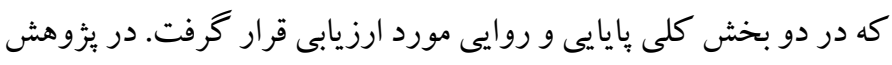

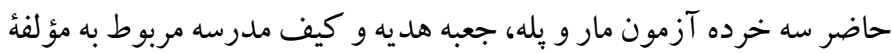

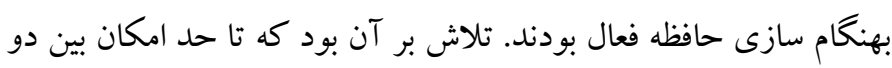

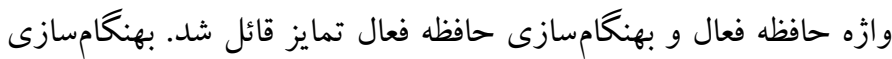

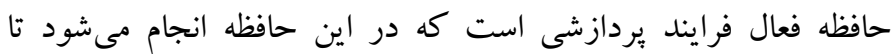
اطلاعات جديد جايكزين اطلاعات قديمى شوند (هامرشتين و همكاران،

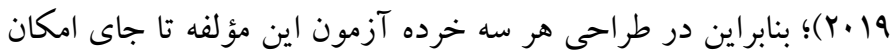

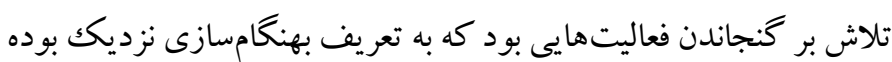
و در بر گيرندهى كليدوازههاى اساسى باشد. همجنين خرده آزمونهاى خط

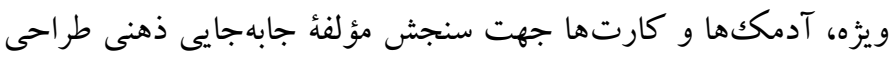

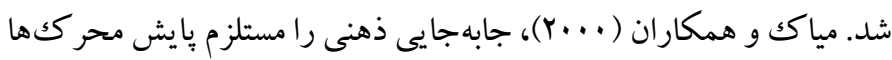
و نگاه رو به جلو و رو به عقب مى دانند. در خرده آزمونهاى طر احى شداه

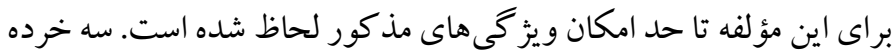

جدول ه ماتريس مؤلفه هاى جر خش يافته با استفاده از روش واريمكس را نشان مىدهد. ه جرخ خش جهت تعيين مدل انجام شده است.

\begin{tabular}{|c|c|c|c|}
\hline مولفه r م & 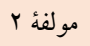 & مولفة 1 & \\
\hline$-\cdot / F F$ & $\cdot / \cdot \Delta$ & $\cdot / V^{F}$ & دامنه (مار و بله) \\
\hline$-\cdot / \cdot \wedge$ & .1 .9 & $\cdot / 9$ & دامنه (جعبة هديه) \\
\hline$\cdot / r$ & $\cdot / / F$ & $\cdot / A F$ & دامنه (كيف مدرسه) \\
\hline$-\cdot / \pi \Delta$ & $\cdot / A 1$ &.$/ 4$ & نمره جابهجايى (خط ويزه) \\
\hline$-\cdot / 10$ & $\cdot / 9$ &.$/ \cdot r$ & نمره جابهجايى (آدمككها) \\
\hline$-\cdot / \cdot \Delta$ & $\cdot / \wedge$ & $\cdot / \cdot \vee$ & طبقات (كارتها) \\
\hline$\cdot / N r$ & $\cdot / \cdot \Delta$ & $-\cdot / T V$ & خطاى تداخل (سيبها) \\
\hline$\cdot 19$ & $-\cdot / \cdot \Delta$ & $-\cdot / T V$ & خطاى نشانه توقف (توب و راكت) \\
\hline $.19 \mathrm{~V}$ & 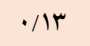 & $-\cdot / \cdot r$ & خطاى تداخل (دستها) \\
\hline
\end{tabular}

همانطور كه مشخص است هريكك از نه خرده آزمون طراحى شده براى هر

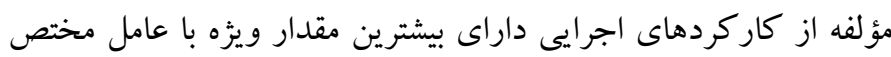

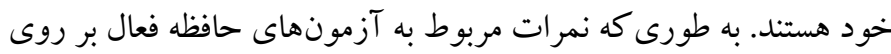
عامل ا، نمرات مربوط به آزمونهاى جابهجايى ذهنى بر روى عامل ب و

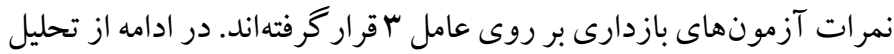
عاملى تأييدى براى ارزيابى برازش مدل اندازهگيرى استفاده شد.

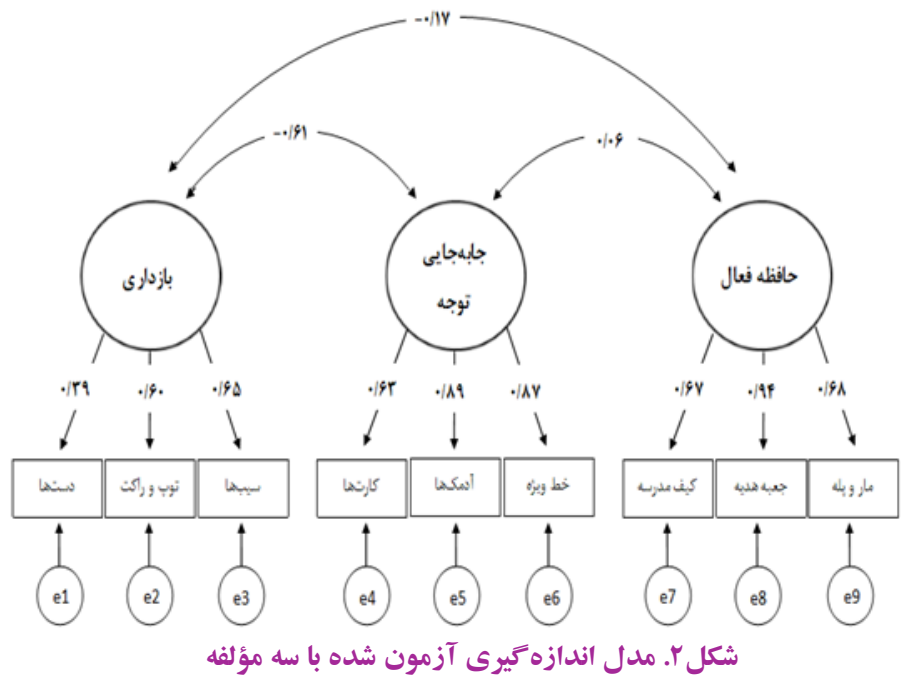

بر اساس اطلاعات شكل rا، خرده آزمونهاى طراحى شده در سه مؤلفه اصلى داراى ضرايب استاندارد قابل قبول هستند. همجنين شاخصهاى برازش مدل نيز حاكى از برازش مطلوب مدل بيشنهادى است (جدول 9). 
هاى مربوط به كاركردهاى اجرايى، پايايى اندك مرحله باز آزمايى مى

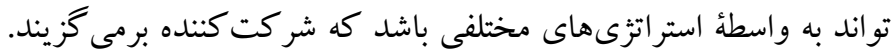
اين تغيير استراتثى بهويزه در تكاليف جديد بيشتر خود را نمايان مى كند.

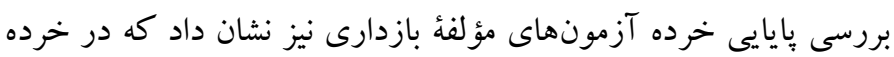

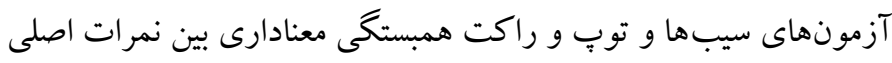

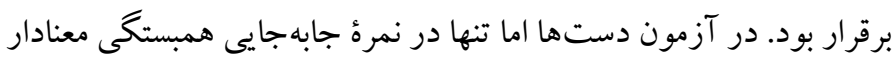
وجود داشت. اخرحهه اين نمره به عنوان شاخص اصلى عملكرد در خرده

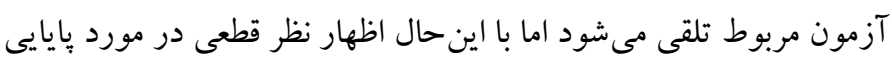
خرده آزمون دستها نياز به بررسى بيشتر دارد. روايى آزمون با استفاده از روش همزمان و سازه انجام شد. در روش همزمان از ضريب همبستحى محاسبه شده بين نمرات شاخص هر خرده آزمون با

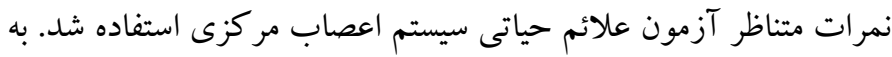

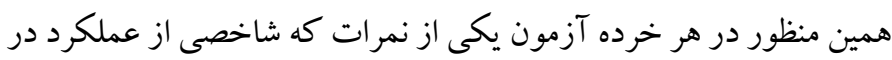

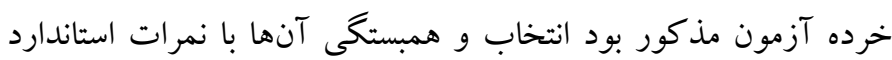

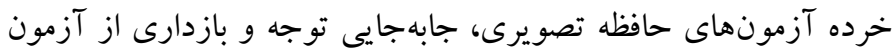
علائم حياتى سيستم اعصاب مركزى محاسبه شد. نتايج نشان داد كه در

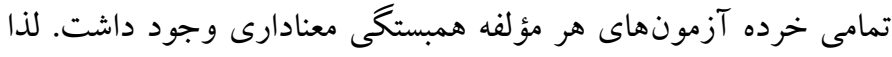
مى توان روايى همزمان مجموعه آزمون را تأييد كرد.

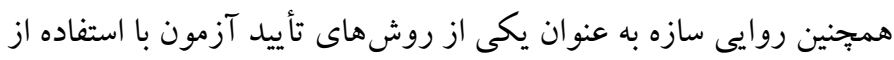
روش تحليل عاملى اكتشافى انجام شد. نتايج اين تحليل نشان داد كه سه عامل داراى ارزش ويزهى بالاتر از ا بودند كه بر روى هم حدود 91 درصد از واريانس را تبيين مى كنند. همجِنين مشخص شد كه خرده آزمو نهاى هر

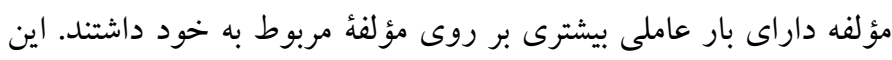
يافته فرضيه سه عامل اصلى كاركردهاى اجر ايى را كه در برخى نظريهها و

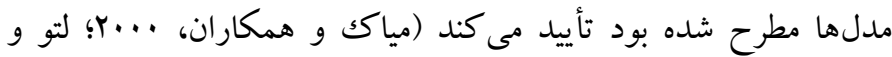

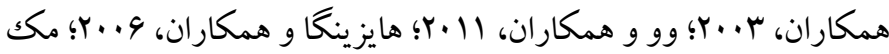

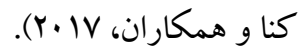
با توجه به مباحث ذكر شده مى توان كفت كه اكرجه اين يثزوهش شامل

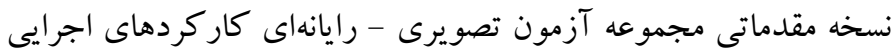
است اما نتايج حاصل نشان مىدهد كه اين آزمون از اعتبار مناسبى جهت

\footnotetext{
${ }^{3}$. Resistance to Proactive Interference
}

آزمون ديخر اين مجموعه جهت سنجش مؤلفهٔ بازدارى طر احى شدند. اين

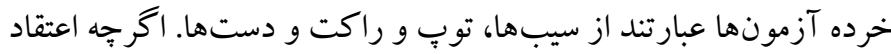

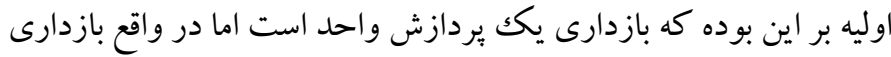

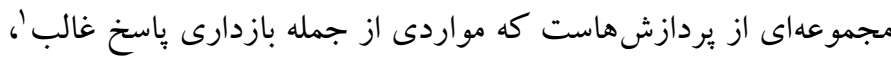

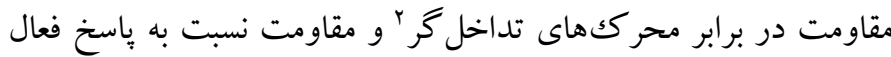

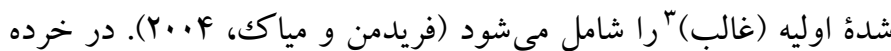
آزمونهاى طراحى شده براى اين مؤلفه تلاش شد تا تعاريف مذكور

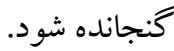
بررسى بايايى آزمون با استفاده از روش باز آزمايى و پِ از حدود دو هنته

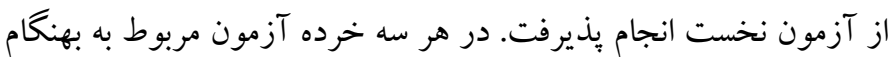

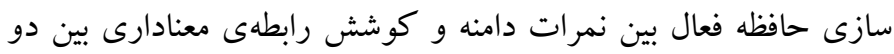
مرحله آزمون وجود داشت. اين موضوع يا يايى خرده آزمونهاى اين مؤلفه

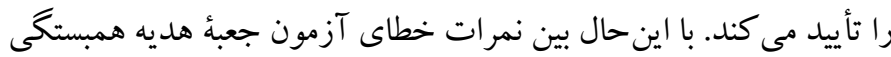

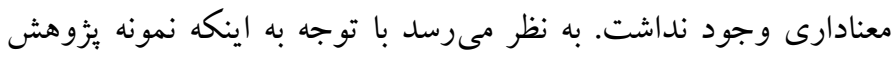

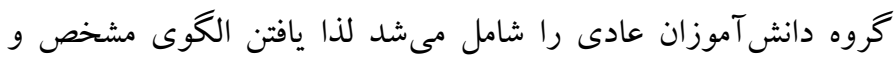

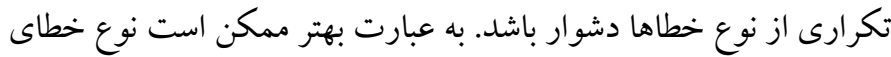
مرتكب شده توسط شركت كنند گان شامل يكك الكوى ياسخدهى تكرار شونده نبوده و بيشتر جنبه تصادفى داشته باشد.

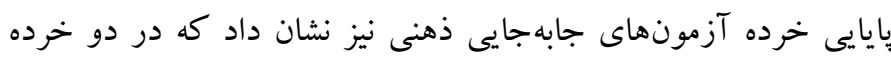

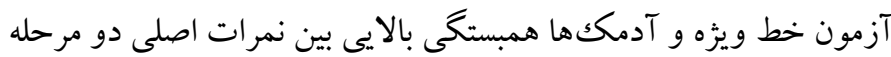
اجراى آزمون وجود داشت كه حاكى از يايايى مناسب خرده آزمونهاست.

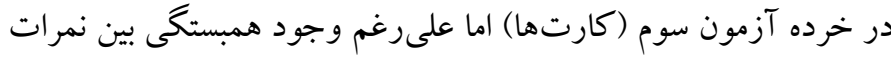
طبقات، ياسخ صحيح و باسخ اشتباه، بين دو نمرهُ ديخر اين خرده آزمون يعنى خطاى درجاماندگى و شكست در حفظ توالى ضرايب همبستخى معنادارى گزارش نشد. اكرجه در اين خرده آزمون نمرة طبقات به به عنوان

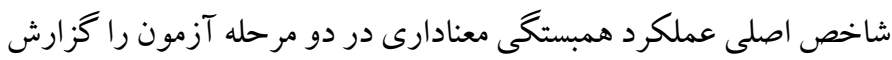

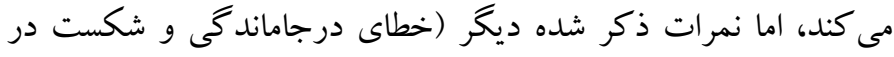
حفظ توالى) نيز به عنوان نمرات خطا، مهم و قابل تفسير هستند. در نتيجه

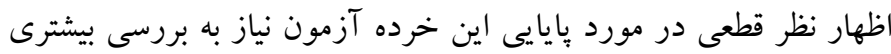

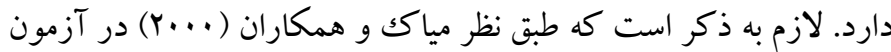


ياد گيرى مرتبط است. همانطور كه ذكر شد يكى از كاربردهاى آتى اين آزمون امكان استفاده از آن براى افراد داراى اختلال خواندن و حساب

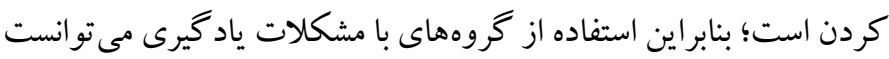
تا حد زيادى به آزمايش اين فرضيه كمك كند.

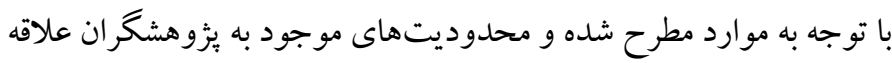

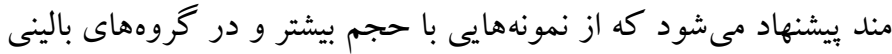
جهت اعتبارسنجى آزمون استفاده كنند. علاوه بر اين هنجاريابى آزمون در سهر

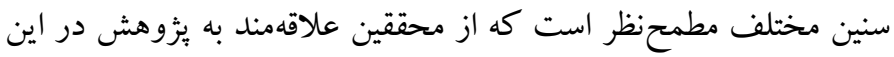
بخش نيز استقبال مى شود.

ملاحضات اخلاقى

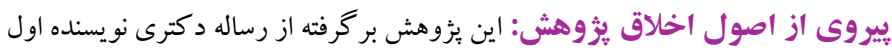

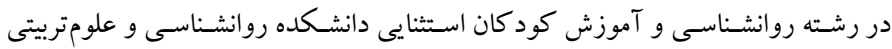

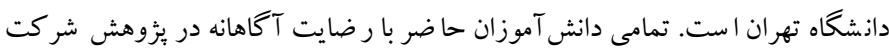

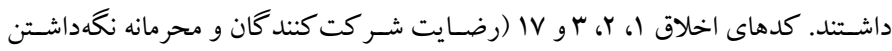

$$
\text { اطلاعات) در اين يزوهش رعايت شده است. }
$$

حامى مالى: اين يثوهش در قالب رساله دكترى و بدون حمايت مالى انجام شده است.

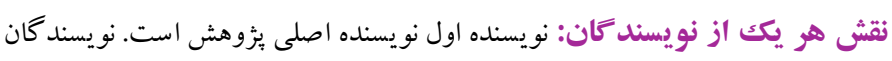

دوم و سوم استادان راهنما و نو يسند كان جهارم و ينجم استادان مشاور هستند. تضاد منافع: نويسند كان هيج تضاد منافعى در رابطه با يُزوهش اعلام نمىنمايند. تشكر و قدردانى: بدينو سيله از زحمات استادان راهنما و مشاور، دانش آموزان شركت كننده در بثزوش و مديران مدارس تشكر و قدردانى به عمل مى آيد.
استفاده در محيط هاى بالينى و يُزوهشى برخوردار است. اخرجه در برخى

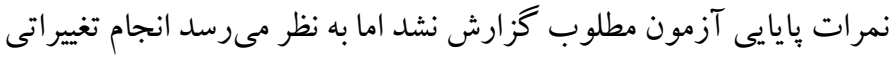

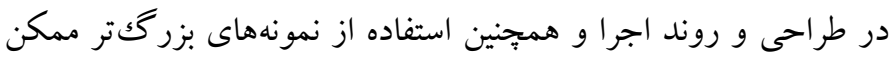
است موجب ارائه نتايج بهترى شود. مجموعه آزمون تصويرى - رايانهاى كار كردهاى داراى ويز گىهايى است كه به صورت خلاصه عبارتند از

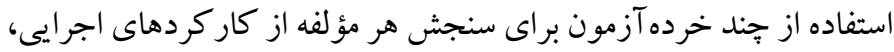

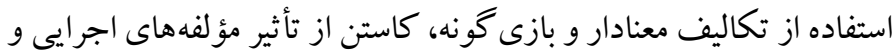

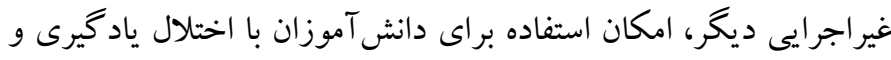

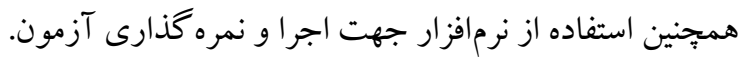

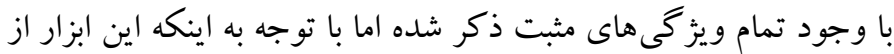

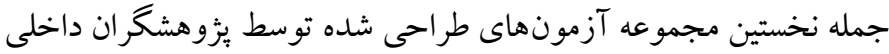

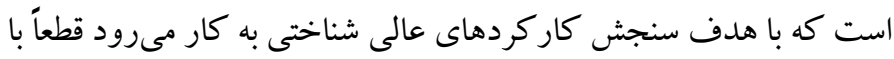

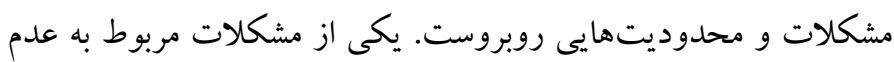
تعيين نمرات و درصدهاى هنجارى است كه امكان مقايسه شر كت كنند كان مدان

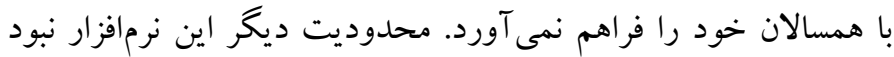
روشى جهت تركيب نمرات شاخص در هر خرده آزمون است. شايان ذكر است كه اين مسائل در گامهاى بعدى توسعه آزمون در نظر كرفته خو اهد

محدوديتهاى اين بُزوهش را مىتوان به دو بخش كلى تقسيم كرد،

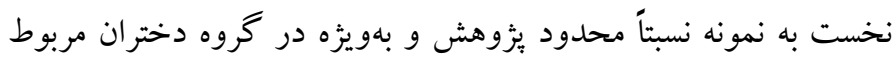
مىشود. دومين محدوديت يُزوهش به عدم استفاده از گروه با اختلال 


\section{References}

Diamond, A. (2013). Executive functions. Annual review of psychology, 64, 135-168. [Link]

Friedman, N. P., \& Miyake, A. (2017). Unity and diversity of executive functions: Individual differences as a window on cognitive structure. Cortex, 86, 186204. [Link]

ghasemi K, kajbaf M B, qamarani A, torkan H. (2020). Effectiveness of domestic package of training executive functions specific for teachers on the signs of attention deficit and hyperactivity disorder (ADHD) of the children. Psychology science, 19 (90), 755-763. (Persian). [Link]

Gualtieri, C. T., \& Johnson, L. G. (2006). Reliability and validity of a computerized neurocognitive test battery, CNS Vital Signs. Archives of Clinical Neuropsychology, 21(7), 623-643. [Link]

Huizinga, M., Dolan, C., \& van der Molen, M. (2006). Age-related change in executive function: Developmental trends and a latent variable analysis. Neuropsychologia, 44, 2017-2036. [Link]

Hull, R., Martin, R. C., Beier, M. E., Lane, D., \& Hamilton, A. C. (2008). Executive function in older adults: a structural equation modeling approach. Neuropsychology, 22(4), 508. [Link]

Jafari F, Arjmandnia A A, Rostami R. (2021). The effect of neuropsychological rehabilitation program on working memory and response inhibition of students with dysgraphia. Psychology science, 20 (98), 233-246. (Persian). [Link]

Lehto, J., Juujarvi, P., Kooistra, L., \& Pulkkinen, L. (2003). Dimensions of executive functioning: Evidence from children. British Journal of Developmental Psychology, 21, 59-80. [Link]

McKenna, R., Rushe, T., \& Woodcock, K. A. (2017). Informing the structure of executive function in children: A meta-analysis of functional neuroimaging data. Frontiers in human neuroscience, 11, 154. [Link]

Miyake, A., \& Friedman, N. P. (2012). The nature and organization of individual differences in executive functions: Four general conclusions. Current directions in psychological science, 21(1), 8-14. [Link]

Miyake, A., Friedman, N. P., Emerson, M. J., Witzki, A. H., Howerter, A., \& Wager, T. D. (2000). The unity and diversity of executive functions and their contributions to complex "frontal lobe" tasks: A latent variable analysis. Cognitive psychology, 41(1), 49-100. [Link]
Munakata, Y. (2001). Graded representations in behavioral dissociations. Trends in cognitive sciences, 5(7), 309-315. [Link]

Posner, M. I., \& Rothbart, M. K. (2007). Research on attention networks as a model for the integration of psychological science. Annu. Rev. Psychol., 58, 123. [Link]

Shokoohi-Yekta M, Zamani N, Pourkarimi J, Sharifi A. (2015). Effects of cognitive interventions based on social problem solving on improving interpersonal relationships and executive functions of slowlearner students. Psychology science, 13 (52), 490504. (Persian). [Link]

Wu, K. K., Chan, S. K., Leung, P. W. L., Liu, W.-S., Leung, F. L. T., \& Ng, R. (2011). Components and developmental differences of executive functioning for school-aged children. Developmental Neuropsychology, 36, 319-337. [Link] 